\title{
A Fuzzy Modeling Approach for Replicated Response Measures Based on Fuzzification of Replications with Descriptive Statistics and Golden Ratio
}

\author{
Özlem TÜRKŞEN*1
}

${ }^{1}$ Ankara University, Faculty of Science, Department of Statistics, 06100, Ankara

(Alınış / Received: 16.10.2017, Kabul / Accepted: 09.02.2018, Online Yayınlanma / Published Online: 23.03.2018)

\section{Keywords}

Replicated response

measures,

Fuzzy least squares, Triangular type-1 fuzzy

numbers,

Golden ratio

\begin{abstract}
Some of the experimental designs can be composed of replicated response measures in which the replications cannot be identified exactly and may have uncertainty different than randomness. Then, the classical regression analysis may not be proper to model the designed data because of the violation of probabilistic modeling assumptions. In this case, fuzzy regression analysis can be used as a modeling tool. In this study, the replicated response values are newly formed to fuzzy numbers by using descriptive statistics of replications and golden ratio. The main aim of the study is obtaining the most suitable fuzzy model for replicated response measures through fuzzification of the replicated values by taking into account the data structure of the replications in statistical framework. Here, the response and unknown model coefficients are considered as triangular type-1 fuzzy numbers (TT1FNs) whereas the inputs are crisp. Predicted fuzzy models are obtained according to the proposed fuzzification rules by using Fuzzy Least Squares (FLS) approach. The performances of the predicted fuzzy models are compared by using Root Mean Squared Error (RMSE) criteria. A data set from the literature, called wheel cover component data set, is used to illustrate the performance of the proposed approach and the obtained results are discussed. The calculation results show that the combined formulation of the descriptive statistics and the golden ratio is the most preferable fuzzification rule according to the wellknown decision making method, called TOPSIS, for the data set.
\end{abstract}

\section{Tekrarlı Yanıt Ölçümleri İçin Tekrarların Betimsel İstatistikler ve Altın Oran ile Bulanıklaştırılmasına Dayalı Olușturulan Bir Bulanık Modelleme Yaklaşımı}

\section{Anahtar Kelimeler}

Tekrarlı yanıt ölçümleri, Bulanık en küçük kareler, Üçgensel tip-1 bulanık sayllar,

Altın oran
Özet: Bazı deneysel tasarımlar tekrarlı yanıt ölçümlerini içerebilir. Bu tasarımlarda tekrarlar tam olarak belirlenemeyebilir ve rasgelelikten farklı olarak belirsizlikler içerebilir. Olasılıksal modelleme varsayımlarının sağlanamaması nedeniyle verilerin modellenmesi için klasik regresyon analizi uygun olmayabilir. $\mathrm{Bu}$ durumda, bulanık regresyon analizi bir modelleme aracı olarak kullanılabilir. $\mathrm{Bu}$ çalışmada, tekrarlı yanıt değerleri, tekrarlara ilişkin betimsel istatistiklerin ve altın oranın kullanılması ile yeni bir formda bulanık sayılara dönüștürülmüștür. Çalışmanın temel amacı, tekrarlı değerlerin bulanıklaştırılmasında tekrarların yapısını istatistiksel anlamda dikkate alarak, veri seti için en uygun bulanık modelin elde edilmesini sağlamaktır. Burada, yanıt ve bilinmeyen model katsayıları üçgensel tip-1 bulanık sayılar, girdi değișkenleri kesin değerler olarak ele alınmıştır. Tahmini bulanık modeller, önerilen bulanıklaştırma kurallarına göre bulanık en küçük kareler yaklaşımı kullanılarak elde edilmiştir. Tahmini bulanık modellerin performansları hata kareler ortalamasının karekökü (RMSE) kriteri kullanılarak karşılaștırılmıştır. Literatürde tanımlı bir veri seti üzerinde önerilen yaklaşım uygulanarak elde edilen sonuçlar değerlendirilmiştir. Elde edilen sonuçlar, betimsel istatistikler ve altın oran ile oluşturulan formülasyonun, oldukça iyi bilinen bir karar verme yöntemi olan TOPSIS'e göre, ilgilenilen veri seti için en çok tercih edilen bulanıklaștırma kuralı olduğunu gösterir. 


\section{Introduction}

Statistical regression analysis is the most important tool used by researchers for modeling of the relationship among the response and input variables, and also important for making predictions with minimum error. However, in many real life problems, classical regression analysis cannot be used for model building phase properly due to violation of probabilistic modeling assumptions, which are necessary for statistical inference through ANOVA techniques, e.g. data set has small size, or the errors are not normally distributed, or the relationship between response and input variables has imprecision, or there is uncertainty about the variables different than randomness. There are some cases where the response values cannot be identified exactly. One of these cases is that the response may be composed of replicated measures where the qualification of the response has uncertainty. When there is uncertainty about a number it can be modeled as a fuzzy set in which case it is called a fuzzy number, firstly introduced by Zadeh [1].

In the literature, the application of fuzzy approach in regression analysis is roughly divided into two categories: (i) Tanaka's Linear Programming (LP) approach [2], and (ii) Diamond's Fuzzy Least Squares (FLS) approach [3]. Later on, many studies have been done about fuzzy linear regression and its application. A detailed review on fuzzy regression can be found in [4]. In recent years, some studies have been carried out about modeling of replicated response measures in fuzzy framework. Bashiri and Hosseininezhad [5] is proposed a methodology for optimizing multi response surface in robust design by applying fuzzy set theory and replicated response measured data set is used to illustrate the proposed methodology. And also, Bashiri and Hosseininezhad [6] is developed an approach to multiple response optimization for responses without replicates and with some replicates based on fuzzy concept. Türkşen and Apaydın [7] proposed a modeling approach based on FLS method by using triangular type-1 fuzzy numbers (TT1FNs) for multi response experiments with replicated response measures. Türkşen and Güler [8] applied fuzzy logic based modeling approaches, e.g. FLS Regression, Switching Fuzzy CRegression (SFCR), and Takagi-Sugeno (TS) fuzzy model, on replicated response measured data set and calculated prediction performance of modeling approaches. It is seen that the SFCR gives the better prediction performance according to the root mean square error (RMSE) criteria. Türkşen and Kocadağlı [9] applied triangular type-2 fuzzy numbers for representation of replicated response measures as fuzzy numbers. And also, FLSR is used for estimating of fuzzy model coefficients. Türkşen [10] used Bayesian and fuzzy approaches to model the data sets with replicated response measures.
Comparison of modeling approaches are evaluated by interval arithmetic metrics. In these papers, replicated response measures are transformed to a fuzzy number by using descriptive statistics for each observation unit. In fact, the replicated measures cannot be quantified exactly. Besides, replicated values are different from each other which cause uncertainty different than randomness. Therefore, the natural structure of replicated measures should be taken into account to represent the uncertainty of replicated values properly.

In this study, data structure of the replicated response measures is taken into account for fuzzification of the replicated measures in order to apply fuzzy modeling from a new perspective. For this purpose, descriptive statistics of the replicated response values are used to form response as TT1FNs. Thus, the uncertainty of the replicated response measures is defined according to the character of the replications in statistical manner. Also, in the study, golden ratio, derived from Fibonacci series, is combined with descriptive statistics and it is used to transform replications to the TT1FNs. The main purpose of the study is demonstrating the importance of fuzzification of replicated measures for fuzzy modeling of the data set. It is possible to say that using descriptive statistics with golden ratio gives appropriate fuzzification approach for replicated measured data set according to the RMSE criteria. The paper is organized as follows: In Section 2, fuzzification of replicated measures is given in detail with a brief description about FLS regression. In Section 3, a real data set in the literature is used to illustrate the applicability of the proposed fuzzification approach with comparison results. Finally, discussion and conclusion are given in Section 4.

\section{Material and Method}

\subsection{Design of replicated measures}

In modeling stage of an unknown response, the first basic step is data gathering and proper design of experimental data. Sometimes, the design of the data may be composed by using the replicated measures of the response as given in Table 1.

Table 1. Experimental design for an experimental data set with replicated response measures

\begin{tabular}{|c|c|c|c|c|c|c|c|c|}
\hline \multirow{3}{*}{$\frac{\underline{\text { No }}}{1}$} & \multicolumn{4}{|c|}{ Input levels } & \multirow{2}{*}{\multicolumn{4}{|c|}{$\frac{\text { Response }}{Y}$}} \\
\hline & \multirow{2}{*}{$\begin{array}{l}\mathbf{X}_{1} \\
\mathrm{X}_{11}\end{array}$} & \multirow{2}{*}{$\begin{array}{l}\mathbf{X}_{2} \\
\mathrm{X}_{12}\end{array}$} & \multirow{2}{*}{$\begin{array}{l}\ldots \\
\ldots \\
\ldots\end{array}$} & \multirow{2}{*}{$\begin{array}{l}\mathbf{X}_{p} \\
\mathrm{X}_{1 \mathrm{p}}\end{array}$} & & & & \\
\hline & & & & & $y_{11}$ & $y_{12}$ & $\ldots$ & $y_{1 r}$ \\
\hline 2 & $x_{21}$ & $x_{22}$ & $\ldots$ & $x_{2 p}$ & $y_{21}$ & $y_{22}$ & $\ldots$ & $y_{2 r}$ \\
\hline$\cdot$ & . & $\cdot$ & & 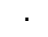 & . & . & & \\
\hline$\cdot$ & . & & $\ldots$ & $\cdot$ & . & . & $\ldots$ & \\
\hline$\dot{5}$ & . &. & & $\cdot$ & . & 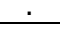 & & \\
\hline $\mathbf{n}$ & $x_{n 1}$ & $x_{n 2}$ & $\ldots$ & $x_{n p}$ & $y_{n 1}$ & $y_{n 1}$ & $\ldots$ & $y_{n 1}$ \\
\hline
\end{tabular}


In Table $1, n$ denotes the number of experimental units and $r$ is the number of replications for the response. It should be noted that each replication is measured for each setting of a group of $p$ input variables. One of the main aim for the experimental data set, designed in Table 1, is modeling of the data set as a function of input variables and replicated response measures. In order to model the replicated data set properly, the uncertainty of the nature of the replicated response measures should be taken into account. For this purpose, in this study, TT1FNs are used to represent vagueness of the replicated response values.

\subsection{Triangular type-1 fuzzy numbers (TT1FNs) and some basic operators}

One of the most useful representation of fuzziness is defining a membership function for the data set. The shape of membership function, e.g. triangular, trapezoidal, Gaussian, helps to classify the fuzzy numbers. In this study, TT1FNs are preferred to use due to easiness of mathematical calculations.

A type-1 fuzzy set $A$ is a set function on universe $D_{A}$ into $[0,1]$, e.g. $\mu_{A}: X \rightarrow[0,1]$. The membership function (MF) of $A$ is denoted $\mu_{A}(x)$ and is called a type-1 MF, e.g. $A=\left\{\left(x, \mu_{A}(x)\right): x \in X\right\}$ in which $0 \leq \mu_{A}(x) \leq 1[11]$.

When the uncertainty is modeled using a type-1 fuzzy set it is called a type- 1 fuzzy number. Let $A$ be a fuzzy set in $R . A$ is called a type-1 fuzzy number if: (i) $A$ is normal, (ii) $A$ is convex, and (iii) $A$ has a bounded support [11].

The MF formula for TT1FN is given below

$$
\mu_{A}(x)=\left\{\begin{array}{ccc}
\left(x-a_{1}\right) /\left(a_{2}-a_{1}\right) & , & a_{1} \leq x<a_{2} \\
\left(a_{3}-x\right) /\left(a_{3}-a_{2}\right) & , & a_{2} \leq x \leq a_{3} \\
0 & , \quad x>a_{3} \text { or } x<a_{1}
\end{array}\right.
$$

where the $A$ can be denoted as $\tilde{A}=\left(a_{1}, a_{2}, a_{3}\right)$. The basic arithmetic operators for TT1FNs are defined in many studies due to wide range of usage of TT1FNs. Here, some elementary operations are given basicly.

Let $\tilde{A}=\left(a_{1}, a_{2}, a_{3}\right)$ and $\tilde{B}=\left(b_{1}, b_{2}, b_{3}\right)$ be two TT1FNs.

Addition: $\tilde{A}+\tilde{B}=\left(a_{1}+b_{1}, a_{2}+b_{2}, a_{3}+b_{3}\right)$

Subtraction: $\tilde{A}-\tilde{B}=\left(a_{1}-b_{3}, a_{2}-b_{2}, a_{3}-b_{1}\right)$

Multiplication: $\tilde{A} \times \tilde{B}=\left(a_{1} b_{1}, a_{2} b_{2}, a_{3} b_{3}\right)$

Scalar Multiplication: Let $\lambda$ be a scalar.

$$
\lambda \tilde{A}=\left\{\begin{array}{cc}
\left(\lambda a_{1}, \lambda a_{2}, \lambda a_{3}\right) & , \quad \lambda>0 \\
\left(-\lambda a_{3},-\lambda a_{2},-\lambda a_{1}\right), & \lambda<0
\end{array}\right.
$$

\subsection{Fuzzification of replicated response measures}

In order to apply fuzzy modeling approach to replicated data set, the replicated response measures should be represented as fuzzy numbers. For this purpose, in this study, replicated measures are transformed to the TT1FNs through the descriptive statistics and the golden ratio. The proposed fuzzification rules are given in detailed.

Let the matrix of observed replicated response measures be

$$
\mathbf{Y}=\left[\begin{array}{c}
\mathbf{Y}_{1} \\
\mathbf{Y}_{2} \\
\cdot \\
\cdot \\
\cdot \\
\mathbf{Y}_{n}
\end{array}\right]=\left[\begin{array}{cccc}
Y_{11} & Y_{12} & \ldots & Y_{1 r} \\
Y_{21} & Y_{22} & \ldots & Y_{2 r} \\
\cdot & \cdot & & \cdot \\
\cdot & \cdot & \ldots & \cdot \\
\cdot & \cdot & & \cdot \\
Y_{n 1} & Y_{n 2} & \ldots & Y_{n r}
\end{array}\right]
$$

where $n$ denotes the number of units and $r$ denotes number of replications for each unit. The triangular fuzzy values of the each unit is given as

$$
\mathbf{Y}=\left[\begin{array}{c}
\tilde{\mathbf{Y}}_{1} \\
\tilde{\mathbf{Y}}_{2} \\
\cdot \\
\cdot \\
\tilde{\mathbf{Y}}_{n}
\end{array}\right]=\left[\begin{array}{c}
\left(Y_{1}^{l}, Y_{1}^{c}, Y_{1}^{u}\right) \\
\left(Y_{2}^{l}, Y_{2}^{c}, Y_{2}^{u}\right) \\
\cdot \\
\cdot \\
\cdot \\
\left(Y_{n}^{l}, Y_{n}^{c}, Y_{n}^{u}\right)
\end{array}\right]
$$

Thus, the fuzzy responses $\tilde{\mathbf{Y}}_{i}=\left(Y_{i}^{l}, Y_{i}^{c}, Y_{i}^{u}\right)$, $i=1,2, \ldots, n$, are obtained by using different fuzzification rules for each unit as shown below:

Rule-1:

$\begin{aligned} & Y_{i}^{l}=\bar{Y}_{i .}-2 \operatorname{stddev}\left(Y_{i j}\right) \\ & Y_{i}^{c}=\bar{Y}_{i .} \\ & Y_{i}^{u}=\bar{Y}_{i .}+2 \operatorname{stddev}\left(Y_{i j}\right)\end{aligned}, i=1,2, \ldots, n, j=1,2, \ldots, r$

where $\bar{Y}_{i .}=\frac{\sum_{j=1}^{r} Y_{i j}}{r}$ and $\operatorname{std} \operatorname{dev}\left(Y_{i j}\right)=\frac{\sum_{j=1}^{r}\left(Y_{i j}-\bar{Y}_{i .}\right)^{2}}{r-1}$.

It should be noted here that the $\bar{Y}_{i .}, i=1,2, \ldots, n$, is the mean of observed replicated response measures for each unit and $2 \times$ stddev is assumed as the spread for fuzzification of the replicated response measures to obtain an interval similar as a 95\% confidence interval. 
Rule-2:

$$
\begin{aligned}
& Y_{i}^{l}=Y_{i(1)} \\
& Y_{i}^{c}=\bar{Y}_{i .} \quad, i=1,2, \ldots, n, j=1,2, \ldots, r \\
& Y_{i}^{u}=Y_{i(r)}
\end{aligned}
$$

where $Y_{i(1)}$ and $Y_{i(r)}$ are the smallest and the largest order statistics for each unit.

Rule-3:

$$
\begin{aligned}
& Y_{i}^{l}=Y_{i(1)} \\
& Y_{i}^{c}=\operatorname{med}\left(Y_{i j}\right), i=1,2, \ldots, n, j=1,2, \ldots, r \\
& Y_{i}^{u}=Y_{i(r)}
\end{aligned}
$$

in which $\operatorname{med}\left(Y_{i j}\right)$ represents the median of the replicated response measures for each unit.

Rule-4:

$$
\begin{aligned}
& Y_{i}^{l}=Y_{i(1)} \\
& Y_{i}^{c}=Y_{i(1)}+R_{i} \times \rho, \quad i=1,2, \ldots, n \\
& Y_{i}^{u}=Y_{i(r)}
\end{aligned}
$$

where $R_{i}$ is called as the range and is obtained by substracting the smallest observation from the largest observation for each unit, i.e. $R_{i}=Y_{i(r)}-Y_{i(1)}$, $i=1,2, \ldots, n$. Here, $\rho$ is the golden ratio and taken equal to 0.618 . The golden ratio, also sometimes called golden section, golden mean, golden number, divine proportion, divine section, golden proportion, is the limit of consecutive Fibonacci numbers, detailed information can be seen in Dunlap [12], that is

$$
\lim _{n \rightarrow \infty} \frac{F_{n+1}}{F_{n}}=\alpha=\frac{1+\sqrt{5}}{2}=1.618,
$$

and

$$
\lim _{n \rightarrow \infty} \frac{F_{n}}{F_{n+1}}=\beta=-0.618 .
$$

Rule-5:

$$
\begin{aligned}
& Y_{i}^{l}=Y_{i(1)} \\
& Y_{i}^{c}=Y_{i(1)}+I Q R_{i} \times \rho, i=1,2, \ldots, n \\
& Y_{i}^{u}=Y_{i(r)}
\end{aligned}
$$

in which $I Q R_{i}$ is interquartile range of replicated response measures for each unit.

\subsection{Fuzzy least squares regression}

A general form of the fuzzy linear regression model, used in this study, can be given as

$$
\tilde{\mathbf{Y}}=\mathbf{X} \tilde{\boldsymbol{\beta}}+\tilde{\boldsymbol{\varepsilon}}
$$

where the observed response values, model coefficients and errors are assumed as TT1FNs, denoted as $\tilde{\mathbf{Y}}=\left[\begin{array}{lll}\tilde{\mathbf{Y}}_{1} & \tilde{\mathbf{Y}}_{2} \ldots \tilde{\mathbf{Y}}_{n}\end{array}\right]^{\prime}, \tilde{\boldsymbol{\beta}}=\left(\boldsymbol{\beta}^{l}, \boldsymbol{\beta}^{c}, \boldsymbol{\beta}^{u}\right)$, and $\tilde{\boldsymbol{\varepsilon}}=\left(\boldsymbol{\varepsilon}^{l}, \boldsymbol{\varepsilon}^{c}, \boldsymbol{\varepsilon}^{u}\right)$, respectively. Here, the inputs are considered as crisp values. In order to estimate the unknown fuzzy model parameters, FLS method is used. The FLS aims to obtain fuzzy parameter estimates by minimizing the sum of the squared distance between observed and predicted fuzzy response values, formalized as

$$
\min _{\tilde{\boldsymbol{\beta}}} \phi(\tilde{\boldsymbol{\beta}})=\min _{\tilde{\boldsymbol{\beta}}}\left(d^{2}(\tilde{\mathbf{Y}}, \hat{\tilde{\mathbf{Y}}})\right)
$$

where $\hat{\tilde{\mathbf{Y}}}$ represents predicted triangular fuzzy response values. In this case, vertex method, proposed by Diamond [3], can be used to calculate the distance between $\tilde{\mathbf{Y}}$ and $\hat{\tilde{\mathbf{Y}}}$ as following

$d^{2}(\tilde{\mathbf{Y}}, \hat{\tilde{\mathbf{Y}}})=\frac{1}{3}\left(\left(\mathbf{Y}^{l}-\hat{\mathbf{Y}}^{l}\right)^{2}+\left(\mathbf{Y}^{c}-\hat{\mathbf{Y}}^{c}\right)^{2}+\left(\mathbf{Y}^{u}-\hat{\mathbf{Y}}^{u}\right)^{2}\right)(1$

It is clear that Equation (11) gives sum of squared errors. The root mean of sum of squared error terms, RMSE, is preferred to use as a criteria to evaluate the prediction performances of the fuzzy regression models whose response values are composed with the proposed five fuzzification rules of the replicated response measures.

\section{Results}

In this section, a well-known data set, wheel cover component data set, is chosen from the literature. It is originally given in Harper et al. [13]. The purpose of the data set is to determine the effects of seven injection molding input variables (denoted as $X_{1}, X_{2}, \ldots, X_{7}$ ) on the equality characteristics of the component which are considered as responses. These are measured by the total weight and the balance which are denoted as $Y_{1}$ (in grams) and $Y_{2}$ (in inch-ounces). Throughout the work, it is assumed that the responses are uncorrelated. The experiment was conducted in a $2^{7-4}$ fractional factorial design with five replications in each unit. The two levels of each input variables $X_{i j}, i=$ $1,2, \ldots, 8, j=1,2, \ldots, 7$ are coded as -1 and +1 [8]. The experimental data set is given in Table 2 . The boxplots of the replicated response measures for each 
Table 2. The wheel cover component data set Input levels

\section{Responses}

\begin{tabular}{|c|c|c|c|c|c|c|c|c|c|c|c|c|c|c|c|c|c|}
\hline & & & & & & & & & & Y1 & & & & & $\mathrm{Y2}$ & & \\
\hline No & $\mathbf{X}_{1}$ & $\mathbf{X}_{2}$ & $\mathbf{X}_{3}$ & $\mathbf{X}_{4}$ & $\mathbf{X}_{5}$ & $\mathbf{X}_{6}$ & $\mathbf{X}_{7}$ & $\begin{array}{l}\text { Rep. } \\
1\end{array}$ & $\begin{array}{l}\text { Rep. } \\
2\end{array}$ & $\begin{array}{l}\text { Rep. } \\
3\end{array}$ & $\begin{array}{l}\text { Rep. } \\
4\end{array}$ & $\begin{array}{l}\text { Rep. } \\
5\end{array}$ & $\begin{array}{l}\text { Rep. } \\
1\end{array}$ & $\begin{array}{l}\text { Rep. } \\
2\end{array}$ & $\begin{array}{l}\text { Rep. } \\
3\end{array}$ & $\begin{array}{l}\text { Rep. } \\
4\end{array}$ & $\begin{array}{l}\text { Rep. } \\
5\end{array}$ \\
\hline 1 & -1 & -1 & -1 & -1 & -1 & -1 & -1 & 711.9 & 713.4 & 712.3 & 712.4 & 711.9 & 0.59 & 0.59 & 0.47 & 0.71 & 0.63 \\
\hline 2 & -1 & -1 & -1 & +1 & +1 & +1 & +1 & 725 & 720.1 & 711.8 & 723.9 & 720.9 & 0.70 & 0.91 & 1.13 & 0.79 & 0.78 \\
\hline 3 & -1 & +1 & +1 & -1 & -1 & +1 & +1 & 711.6 & 711.7 & 711.3 & 712.1 & 711.7 & 0.56 & 0.44 & 0.46 & 0.53 & 0.46 \\
\hline 4 & -1 & +1 & +1 & +1 & +1 & -1 & -1 & 733.7 & 724.1 & 732 & 732.7 & 733.3 & 1.5 & 1.55 & 1.38 & 1.45 & 1.45 \\
\hline 5 & +1 & -1 & +1 & -1 & +1 & -1 & +1 & 725.4 & 721.6 & 722.6 & 723.1 & 721.1 & 1.25 & 1.36 & 1.51 & 1.22 & 1.25 \\
\hline 6 & +1 & -1 & +1 & +1 & -1 & +1 & -1 & 728.1 & 721.1 & 722.9 & 723 & 719.7 & 1.17 & 0.97 & 0.98 & 0.98 & 0.73 \\
\hline 7 & +1 & +1 & -1 & -1 & +1 & +1 & -1 & 726.6 & 731.4 & 731.4 & 729.6 & 731.3 & 1.52 & 1.58 & 1.61 & 1.40 & 1.57 \\
\hline 8 & +1 & +1 & -1 & +1 & -1 & -1 & +1 & 714.3 & 714.4 & 713.6 & 716.3 & 714.6 & 0.57 & 0.51 & 0.44 & 0.44 & 0.56 \\
\hline
\end{tabular}

unit are given in Figure 1 and Figure 2 for the first and the second responses, repectively.

It is clear to say from Figures 1-2 that the replicated response measures are not symmetrically distributed. The replications have skewed distribution. Therefore, $R, I Q R$ and med values of replications will provide more information to construct triangular fuzzy response values. The data sets with the fuzzy response values, composed according to the five fuzzification rules, are given in Table 3. Predicted fuzzy model parameters are obtained by minimizing the objective function, given in Equation (10), according to the each fuzzification rule. The RMSE values are calculated for each predicted fuzzy responses, $\hat{\tilde{\mathbf{Y}}}_{1}$ and $\hat{\tilde{\mathbf{Y}}}_{2}$, and presented in Table 3.

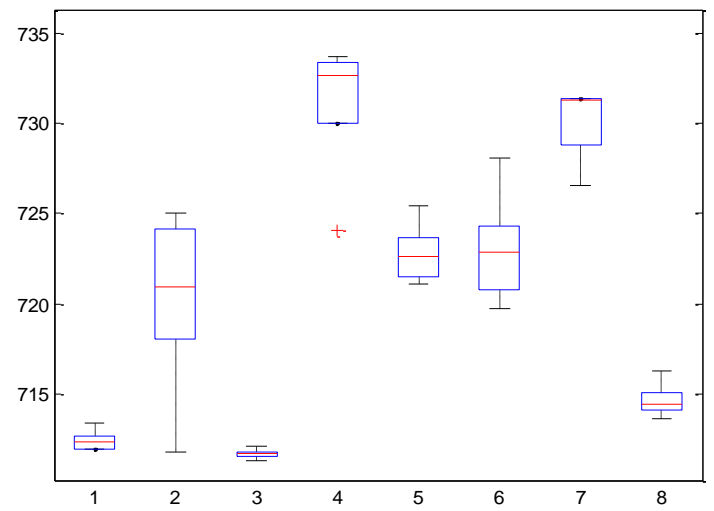

Figure 1. Box-plots of the replications of the first response for each unit

It can be easily seen from Table 3 that the smallest RMSE values of $\hat{\tilde{\mathbf{Y}}}_{1}$ and $\hat{\tilde{\mathbf{Y}}}_{2}$ are 13.9738 and 0.4177 which are related to Rule-5 and Rule-4, respectively. The common trait of the Rules 4-5 is that both rules are composed with variation of replicated response measures, e.g. $R, I Q R$. The predicted fuzzy response models, which have the smallest RMSE values, are given below:

$$
\begin{aligned}
\hat{\tilde{Y}}_{1} & =(717.5125,721.0119,723.175)+(-0.4,2.359,5.2625) X_{1} \\
& +(-2.0375,0.6536,3.625) X_{2}+(-1.2375,1.607,4.425) X_{3} \\
& +(-1.6375,1.5256,4.025) X_{4}+(1.7125,4.8166,7.375) X_{5} \\
& +(-6.1,-3.3174,-0.4375) X_{7}
\end{aligned}
$$

and

$$
\begin{aligned}
& \hat{\tilde{Y}}_{2}=(0.8475,1.0043,1.1013)+(-0.02,0.1085,0.2338) X_{1} \\
& +(-0.0313,0.0958,0.2225) X_{3}+(0.2112,0.3406,0.465) X_{5} \\
& +(-0.28,-0.1545,-0.0262) X_{7}
\end{aligned}
$$

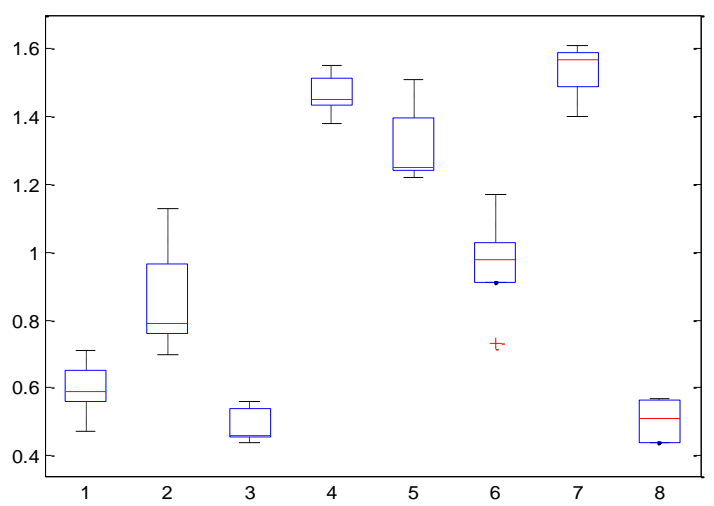

Figure 2. Box-plots of the replications of the second response for each unit

If someone wants to use the same fuzzification rule for both responses, a compromise fuzzification rule must be chosen among the proposed five rules. In this case, a multi criteria decision making (MCDM) approach should be applied to the RMSE values, given in Table 3. For this purpose, a MCDM approach, TOPSIS method, presented in [14], is preferred to use. Here, the fuzzification rules and responses are considered as alternatives and criteria, respectively. The working principle of the TOPSIS is that the chosen compromise solution among the alternative solutions should have the shortest distance from the positive ideal solution and the farthest distance from the negative ideal solution. By assuming that the both responses have equal importance, relative closeness vector of the fuzzification rules with respect to positive ideal solution is

$$
\mathbf{C}=\left[\begin{array}{lllll}
C_{1} & C_{2} & C_{3} & C_{4} & C_{5}
\end{array}\right]=\left[\begin{array}{lllll}
0 & 0.9979 & 0.9957 & 1 & 0.9931
\end{array}\right] .
$$

It is clear from $C_{i}, i=1,2, \ldots, n$, values that the Rule4 is chosen as a compromise fuzzification rule. Thus, one can use fourth rule for transforming replicated response measures to triangular fuzzy responses for wheel cover component data set. 
Table 3. Observed fuzzy response values composed according to fuzzification rules

\begin{tabular}{|c|c|c|c|c|c|c|c|c|}
\hline & \multicolumn{6}{|c|}{ Observed fuzzy response values } & \multicolumn{2}{|c|}{ RMSE } \\
\hline $\begin{array}{c}\text { Fuzzification } \\
\text { Rules } \\
\end{array}$ & \multicolumn{3}{|c|}{$\tilde{\mathbf{Y}}_{1}$} & \multicolumn{3}{|c|}{$\tilde{\mathbf{Y}}_{2}$} & $\hat{\tilde{\mathbf{Y}}}_{1}$ & $\hat{\tilde{\mathbf{Y}}}_{2}$ \\
\hline \multirow{8}{*}{ Rule-1 } & 711.152 & 712.38 & 713.608 & 0.4246 & 0.598 & 0.7714 & \multirow{8}{*}{22.2414} & \multirow{8}{*}{0.6506} \\
\hline & 709.9625 & 720.34 & 730.7175 & 0.5269 & 0.862 & 1.1971 & & \\
\hline & 711.1073 & 711.68 & 712.2527 & 0.3861 & 0.49 & 0.5939 & & \\
\hline & 723.163 & 731.16 & 739.157 & 1.339 & 1.466 & 1.593 & & \\
\hline & 719.4116 & 722.76 & 726.1084 & 1.0783 & 1.318 & 1.5577 & & \\
\hline & 716.5951 & 722.96 & 729.3249 & 0.6534 & 0.966 & 1.2786 & & \\
\hline & 725.8992 & 730.06 & 734.2208 & 1.3707 & 1.536 & 1.7013 & & \\
\hline & 712.637 & 714.64 & 716.643 & 0.3786 & 0.504 & 0.6294 & & \\
\hline \multirow{8}{*}{ Rule-2 } & 711.9 & 712.38 & 713.4 & 0.47 & 0.598 & 0.71 & \multirow{8}{*}{13.9762} & \multirow{8}{*}{0.4182} \\
\hline & 711.8 & 720.34 & 725 & 0.7 & 0.862 & 1.13 & & \\
\hline & 711.3 & 711.68 & 712.1 & 0.44 & 0.49 & 0.56 & & \\
\hline & 724.1 & 731.16 & 733.7 & 1.38 & 1.466 & 1.55 & & \\
\hline & 721.1 & 722.76 & 725.4 & 1.22 & 1.318 & 1.51 & & \\
\hline & 719.7 & 722.96 & 728.1 & 0.73 & 0.966 & 1.17 & & \\
\hline & 726.6 & 730.06 & 731.4 & 1.4 & 1.536 & 1.61 & & \\
\hline & 713.6 & 714.64 & 716.3 & 0.44 & 0.504 & 0.57 & & \\
\hline \multirow{8}{*}{ Rule-3 } & 711.9 & 712.3 & 713.4 & 0.47 & 0.59 & 0.71 & \multirow{8}{*}{13.9774} & \multirow{8}{*}{0.4187} \\
\hline & 711.8 & 720.9 & 725 & 0.7 & 0.79 & 1.13 & & \\
\hline & 711.3 & 711.7 & 712.1 & 0.44 & 0.46 & 0.56 & & \\
\hline & 724.1 & 732.7 & 733.7 & 1.38 & 1.45 & 1.55 & & \\
\hline & 721.1 & 722.6 & 725.4 & 1.22 & 1.25 & 1.51 & & \\
\hline & 719.7 & 722.9 & 728.1 & 0.73 & 0.98 & 1.17 & & \\
\hline & 726.6 & 731.3 & 731.4 & 1.4 & 1.57 & 1.61 & & \\
\hline & 713.6 & 714.4 & 716.3 & 0.44 & 0.51 & 0.57 & & \\
\hline \multirow{8}{*}{ Rule-4 } & 711.9 & 712.827 & 713.4 & 0.47 & 0.6183 & 0.71 & \multirow{8}{*}{13.9766} & \multirow{8}{*}{0.4177} \\
\hline & 711.8 & 719.9576 & 725 & 0.7 & 0.9657 & 1.13 & & \\
\hline & 711.3 & 711.7944 & 712.1 & 0.44 & 0.5142 & 0.56 & & \\
\hline & 724.1 & 730.0328 & 733.7 & 1.38 & 1.4851 & 1.55 & & \\
\hline & 721.1 & 723.7574 & 725.4 & 1.22 & 1.3992 & 1.51 & & \\
\hline & 719.7 & 724.8912 & 728.1 & 0.73 & 1.0019 & 1.17 & & \\
\hline & 726.6 & 729.5664 & 731.4 & 1.4 & 1.5298 & 1.61 & & \\
\hline & 713.6 & 715.2686 & 716.3 & 0.44 & 0.5203 & 0.57 & & \\
\hline \multirow{8}{*}{ Rule-5 } & 711.9 & 712.3635 & 713.4 & 0.47 & 0.5256 & 0.71 & \multirow{8}{*}{13.9738} & \multirow{8}{*}{0.4193} \\
\hline & 711.8 & 715.6007 & 725 & 0.7 & 0.8267 & 1.13 & & \\
\hline & 711.3 & 711.4699 & 712.1 & 0.44 & 0.491 & 0.56 & & \\
\hline & 724.1 & 726.1857 & 733.7 & 1.38 & 1.4294 & 1.55 & & \\
\hline & 721.1 & 722.4596 & 725.4 & 1.22 & 1.3158 & 1.51 & & \\
\hline & 719.7 & 721.8785 & 728.1 & 0.73 & 0.8026 & 1.17 & & \\
\hline & 726.6 & 728.1759 & 731.4 & 1.4 & 1.4603 & 1.61 & & \\
\hline & 713.6 & 714.1562 & 716.3 & 0.44 & 0.5157 & 0.57 & & \\
\hline
\end{tabular}

\section{Discussion and Conclusion}

In this study, fuzzy regression analysis based on FLS approach, is used for modeling of the replicated response measured data set. In order to apply fuzzy modeling, replicated response measures are transformed to TT1FNs by using newly proposed fuzzification rules, based on descriptive statistics and golden ratio. In the present study, the uncertainty of the replicated response measures is handled in fuzzy framework by taking into account to the data structure of replications via statistical data mining. Proposed rules for fuzzification of replicated response measures and fuzzy modeling approach are demonstrated on a real experimental data set which is defined in the literature. The RMSE values of predicted fuzzy responses are calculated for prediction performances of the predicted fuzzy models in which the observed responses are fuzzified by using fuzzification rules. Calculation results show that the compromise fuzzification rule, decided through the TOPSIS method, is obtained by combining descriptive statistics and golden ratio for the wheel cover component data set.

\section{References}

[1] Zadeh, L.A. 1965. Fuzzy sets. Information Control, 338-353.

[2] Tanaka, H., Uejima, S., Asai, K. 1982. Linear Regression Analysis With Fuzzy Model. IEEE Transactions On Systems, Man, And Cybernetics, 12(6), 903-907.

[3] Diamond, P. 1988. Fuzzy least squares. Information Sciences, 46, 141-157. 
[4] Ubale, A.B., Sananse, S. L. 2015. Fuzzy Regression Model and Its Application: A Review. International Journal of Innovative Research in Science, Engineering and Technology, 4(11), 10853-10860.

[5] Bashiri, M., Hosseininezhad, S.J. 2009. A Fuzzy Programming for Optimizing Multi Response Surface in Robust Designs. Journal of Uncertain Systems, 3(3), 163-173.

[6] Bashiri, M., Hosseininezhad, S.J. 2012. Fuzzy Development of Multiple Response Optimization. Group Decision and Negotiation, 21(3), 417-438.

[7] Türkşen, Ö., Apaydın, A. 2014. A Modeling Approach Based on Fuzzy Least Squares Method for Multi-Response Experiments with Replicated Measures. Chaos, Complexity and Leadership 2012 Springer Proceedings in Complexity, Springer Netherlands, 153-158.

[8] Türkşen, Ö., Güler, N. 2015. Comparison of fuzzy logic based models for the multiresponse surface problems with replicated response measures. Applied Soft Computing, $37,887-896$.

[9] Türkșen, Ö., Kocadağlı, O. 2015. Fuzzy Modeling for Replicated Response Measures by
Using Type-2 Fuzzy Numbers. The $4^{\text {th }}$ International Fuzzy Systems Symposium Proceedings Book, 5-6 November 2015, 464468.

[10] Türkșen, Ö. 2016. Analysis of Response Surface Model Parameters with Bayesian Approach and Fuzzy Approach. International Journal of Uncertainty, Fuzziness and Knowledge-Based Systems, 24(1), 109-122.

[11] Mendel, J.M. 2017. Type-1 Fuzzy Sets and Fuzzy Logic. Uncertain Rule-Based Fuzzy Systems, Springer International Publishing AG, 25-99.

[12] Dunlap, R.A. 1997. The Golden Ratio and Fibonacci Numbers. World Scientific Publishing, London. 157s.

[13] Harper, D., Kosbe, M., Peyton, L. 1987. Optimization of Ford Taurus Wheel Cover Balance. Fifth Symposium on Taguchi Methods, 527-539.

[14] Chen, S.J., Hwang, C.L. 1992. Fuzzy Multiple Attribute Decision Making: Methods and Applications. Springer-Verlag, Berlin, 536s. 